\title{
PENGEMBANGAN METODE DETEKSI TINGKAT KEMATANGAN BUAH MELON BERDASARKAN TEKSTUR KULIT BUAH DENGAN MENGGUNAKAN METODE EKSTRAKSI CIRI STATISTIK DAN SUPPORT VECTOR MACHINE (SVM)
}

\author{
Agung Prayoga ${ }^{1}$, Hilmi Abidzar Tawakal ${ }^{2}$, Reza Aldiansyah ${ }^{3}$ \\ ${ }^{1,2}$ Teknik Informatika, Sistem Informasi, Sekolah Tinggi Teknologi Terpadu Nurul Fikri \\ Kampus B Sekolah Tinggi Teknologi Terpadu Nurul Fikri, Jln. Lenteng Agung Raya No. 20 Depok \\ Email : agungprayoga088@gmail.com, hilmi.tawakal@gmail.com, reza.aldi@gmail.com
}

\begin{abstract}
ABSTRAK
Penelitian ini diajukan untuk mendeteksi tingkat kematangan buah melon berdasarkan tekstur kulit buah. Pada penelitian ini menggunakan 450 data buah melon yang terbagi atas 300 data untuk proses training dan 150 data untuk proses testing. Metode yang digunakan dalam penelitian kali ini adalah metode Ekstraksi Ciri Statistik untuk proses ekstraksi fitur, dan metode support vector machine untuk proses pengambilan keputusan tingkat kematangan buah melon. Hasil akurasi yang diperoleh dalam penelitian ini adalah 76.00\%. Sistem ini sangat membantu masyarakat dalam mendeteksi tingkat kematangan buah melon.
\end{abstract}

\section{PENDAHULUAN}

\section{Latar Belakang}

Melon (Cucumis melo L.) merupakan buah yang berasal dari suku labu-labuan atau Cucurbitacea [1]. Melon merupakan buah yang kaya akan kandungan gizi dan baik untuk kesehatan [2].

Mengkonsumsi buah melon dapat mencegah penyakit sariawan, luka pada tepi mulut, penyakit mata, radang saraf, sebagai anti kanker, dan menurunkan resiko stroke [3].

Saat ini, tersebar 94 varietas melon unggulan di Indonesia, salah satunya adalah jenis Sky Rocket Melon. Varietas Sky Rocket Melon merupakan jenis melon yang paling banyak ditanam. Ditinjau dari data produksi nasional, hasil panen total komoditas ini terus mengalami peningkatan, dari 85161 ton pada 2010 hingga 150347 ton pada 2014 [4], yang juga mengindikasikan semakin meningkatnya jumlah permintaan pasar terhadap komoditas ini. Peningkatan produksi dan permintaan terhadap buah melon, khususnya Sky Rocket Melon, belum diimbangi dengan penanganan panen dan pascapanen yang optimal. Panen serentak berdasarkan umur tanaman menyebabkan keseragaman tingkat kematangan buah saat panen masih sangat dipertanyakan. Salah satu parameter penting dalam penentuan kematangan buah melon adalah tingkat ketebalan dan kekasaran jaring-jaring kulit buah melon.

Metode sederhana yang sering dilakukan petani dalam menentukan tingkat kematangan buah melon jenis Sky Rocket Melon ini adalah dengan melihat tingkat ketebalan dan kekasaran dari jaring-jaring kulit pada buah melon. Cara ini dinilai bersifat subjektif karena masing-masing petani memiliki pandangan yang berbeda terhadap melon yang matang jika dilihat dari tingkat ketebalan dan kekasaran dari jaring-jaring kulit buah melon. Sehingga belum ada ketentuan yang akurat untuk menentukan kematangan dari buah melon tersebut. Oleh karena itu, perlu adanya sebuah metode standard untuk mendeteksi buah melon yang sudah matang.

\begin{tabular}{|c|c|c|c|c|c|c|}
\hline $\begin{array}{l}\text { Nama } \\
\text { Peneliti } \\
\end{array}$ & Judul & Tahun & \begin{tabular}{|l|} 
Objek \\
Penelitian \\
\end{tabular} & $\begin{array}{l}\text { Parameter } \\
\text { Penelitian }\end{array}$ & \begin{tabular}{|l} 
Metode \\
Penelitian \\
\end{tabular} & $\begin{array}{l}\text { Hasil } \\
\text { Penelitian }\end{array}$ \\
\hline $\begin{array}{c}\text { Nariratri } \\
\text { Kusumaliski }\end{array}$ & $\begin{array}{l}\text { Pengembangan } \\
\text { Metode Deteksi } \\
\text { Kematangan } \\
\text { Melon (Cucumis } \\
\text { melo L.) Dengan } \\
\text { Respons Impuls } \\
\text { Respostik }\end{array}$ & 2015 & \begin{tabular}{|l|} 
Melon \\
Cantaloupe
\end{tabular} & Ketukan & \begin{tabular}{|l} 
Analisis \\
Diskriminan \\
dan Artificial \\
Neural \\
Network
\end{tabular} & $74.17 \%$ \\
\hline $\begin{array}{l}\text { Wagif } \\
\text { Agusta }\end{array}$ & \begin{tabular}{|l|} 
Deteksi \\
Kematangan \\
Buah Melon \\
Golden Apollo \\
Menggunakan \\
Parameter Sinyal \\
Suara \\
\end{tabular} & 2016 & $\begin{array}{l}\text { Melon } \\
\text { Apollo }\end{array}$ & Ketukan & \begin{tabular}{|l|} 
Short Term \\
Energy, Zero \\
Moment \\
Power, |dan \\
Analisis \\
diskriminan
\end{tabular} & $68.00 \%$ \\
\hline
\end{tabular}

Terdapat beberapa penelitian yang sudah dilakukan untuk mendeteksi buah melon, diantaranya adalah terdapat pada tabel dibawah ini :

Pada penelitian ini akan menggunakan metode ekstraksi ciri statisitik untuk ekstraksi fitur dengan mengambil tekstur dari kulit buah melon dan diubah kedalam bentuk histogram, dan untuk pengklasifikasian tingkat kematangan buah melon digunakan metode Support Vectore Machine. Dimana hasil dari pengklasifikasian ini akan didapatkan tiga klasifikasi yaitu melon matang, setengah matang, dan tidak matang.

Diharapkan dengan adanya penelitian ini dapat membantu petani dan konsumen dalam menentukan tingkat kematangan buah melon yang lebih terstandardisasi. 


\section{Rumusan Masalah}

Berdasarkan latar belakang yang telah diuraikan diatas, rumusan masalah dari penelitian ini adalah :

Apakah metode ekstraksi ciri statistik dan support vectore machine dapat menentukan tingkat kematangan buah melon berdasarkan tekstur kulit buah ?

Bagaimana performa dari metode ekstraksi ciri statistik dan support vectore machine dalam menentukan tingkat kematangan buah melon?

\section{Tujuan Penelitian}

1. Untuk mengetahui apakah metode ekstraksi ciri statistik dan support vectore machine dapat menentukan tingkat kematangan buah melon berdasarkan tekstur kulit buah

2. Untuk mengetahui bagaimana performa dari metode ekstraksi ciri statistik dan support vectore machine dalam menentukan tingkat kematangan buah melon.

\section{Manfaat Penelitian}

Penelitian ini bermanfaat untuk memberi kemudahan kepada konsumen dalam mendeteksi tingkat kematangan buah melon berdasarkan tekstur kulit buah yang terstandardisasi. Hasil dari penelitian ini dapat dijadikan referensi bagi petani dalam memanen melon tanpa menurunkan mutu dari melon tersebut, bagi pedagang dan masyarakat dalam mendeteksi tingkat kematangan melon.

\section{Batasan Masalah}

Batasan masalah dalam penelitian ini adalah :

1. Jenis melon yang digunakan dalam penelitian ini adalah melon jenis Sky Rocket Melon.

2. Metode ekstraksi ciri yang diujikan dalam penelitian ini adalah metode Ekstraksi Ciri Statistik

3. Metode pengambilan keputusan yang diujikan dalam menentukan tingkat kematangan buah melon pada penelitian ini adalah Support Vector Machine (SVM)

\section{LANDASAN TEORI}

\section{Sky Rocket Melon}

Varietas Sky Rocket Melon merupakan jenis melon yang paling banyak ditanam. Varietas ini ada yang berasal dari Jerman, ada juga yang berasal dari Taiwan. Melon ini dapat dipanen pada umur 65 - 70 hari setelah tanam. Buah Melon Sky Rocket berbentuk bulat. Kulit buahnya tebal, dengan permukaan kulit berwarna hijau dan ditutupi sisik seperti jaring-jaring berwarna kelabu. Daging buahnya berwarna kuning kehijauan dan rasanya sangat manis. Dan salah satu penentu tingkat kematangan buah melon ini adalah tingkat ketebalan dan kekasaran dari jaring-jaring kulit buah melon ini (Astuti, 2007).

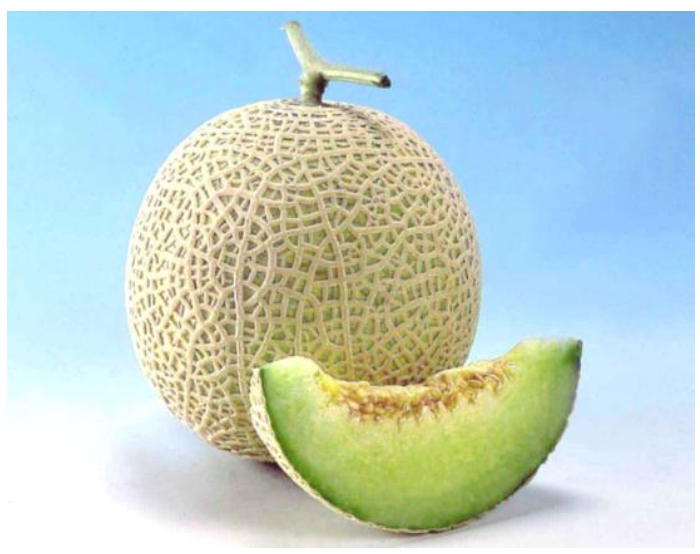

2. Citra

Menurut [5] citra atau gambar merupakan salah satu komponen multimedia yang memegang peranan sangat penting sebagai bentuk dari interpretasi data secara visual. Citra mempunyai karakteristik yang tidak dimiliki oleh data teks, yaitu citra kaya dengan informasi. Seperti diungkapkan oleh sebuah peribahasa yang berbunyi " sebuah gambar bermakna lebih dari seribu kata ". Maksudnya tentu sebuah gambar dapat memberikan informasi yang lebih banyak daripada informasi tersebut disajikan dalam bentuk kata-kata (tekstual).

\section{Pengolahan Citra}

Seperti dijelaskan pada subbab sebelumnya bahwa sebuah citra kaya akan informasi, namun seringkali sebuah citra mengalami penurunan mutu atau kualitas, misalnya pada citra terdapat cacat atau adanya derau (noise), warnanya terlalu gelap atau terlalu terang, citra kurang tajam, citra tidak jelas atau mengalami blurring, dan lain sebagainya. Tentu saja hal tersebut dapat mempersulit dalam proses interpretasi karena sebagian informasi yang terdapat pada citra tersebut hilang.

Untuk mengatasi permasalahan tersebut maka citra tersebut perlu diolah sehingga menghasilkan citra baru yang memiliki kualitas lebih baik. Bidang studi yang mempelajari proses tersebut adalah pengolahan citra (image processing). Sehingga dapat disimpulkan bahwa pengolahan citra merupakan suatu proses yang dilakukan pada sebuah citra, khusus dengan menggunakan alat bantu komputer, untuk menghasilkan sebuah citra baru yang memiliki kualitas yang lebih baik [6]. 


\section{Tekstur Citra}

Tekstur dapat menunjukkan ciri khusus dari sebuah permukaan dan struktur pada objek atau region. Tekstur dicirikan sebagai distribusi spasial dari derajat keabuan didalam sekumpulan pixel-pixel yang bertetangga. Dapat pula dikatakan bahwa tekstur (texture) adalah sifat-sifat atau karakteristik yang dimiliki oleh suatu daerah yang cukup besar sehingga secara alami sifat tersebut dapat berulang dalam daerah tersebut.

Analisis tekstur lazim dimanfaatkan sebagai proses untuk melakukan klasifikasi dan interpretasi citra. Suatu proses klasifikasi citra berbasis analisis tekstur pada umumnya membutuhkan tahapan ekstraksi ciri, yang dapat terbagi dalam tiga macam metode yaitu metode statistik, metode spektral dan metode struktural. Metode statistik menggunakan perhitungan statistik distribusi derajat keabuan (histogram) dengan mengukur tingkat kekontrasan, granularitas, dan kekasaran suatu daerah dari hubungan ketetanggaan antar piksel di dalam citra. Paradigma statistik ini penggunaannya tidak terbatas, sehingga sesuai untuk tekstur-tekstur alami yang tidak terstruktur dari sub pola dan himpunan aturan (mikrostruktur) [7].

\section{Ekstraksi Ciri Statistik}

Ekstraksi ciri merupakan metode pengambilan ciri yang didasarkan pada karakteristik histogram citra. Histogram menunjukkan probabilitas kemunculan nilai derajat keabuan piksel pada suatu citra.

\section{Support Vector Machine}

Support Vector Machine (SVM) merupakan suatu teknik untuk melakukan prediksi, baik dalam kasus klasifikasi maupun regresi. Support Vector Machine pertama kali diperkenalkan oleh Vapnik pada tahun 1992 sebagai rangkaian harmonis konsep-konsep unggulan dalam bidang pattern recognition.

Support Vector Machine (SVM) merupakan sistem pembelajaran yang pengklasifikasiannya menggunakan ruang hipotesis berupa fungsi-fungsi linear dalam sebuah ruang fitur (feature space) berdimensi tinggi, dilatih dengan algoritma pembelajaran yang didasarkan pada teori optimasi dengan mengimplementasikan learning bias yang berasal dari teori pembelajaran statistik. SVM menggunakan metode learning machine yang bekerja atas prinsip Structural Risk Minimization (SRM) dengan tujuan menemukan hyperplane terbaik yang memisahkan dua buah class pada input space [8].

SVM berusaha menemukan fungsi pemisah (hyperplane) terbaik diantara fungsi yang tidak terbatas jumlahnya. Hyperplane pemisah terbaik antara kedua kelas dapat ditemukan dengan mengukur margin hyperplane tersebut dan mencari titik maksimalnya. Pada metode Support Vector Machine (SVM) hanya terdapat sejumlah data terpilih yang berkonstribusi untuk membentuk model yang akan digunakan dalam klasifikasi yang akan dipelajari [9]. Hal tersebut menjadi kelebihan SVM, karena tidak semua data latih akan dipandang untuk dilibatkan dalam setiap iterasi pelatihannya. Dengan demikian SVM dianggap bisa lebih cepat daripada metode lainnya.

Ilustrasi pemisahan kelas di SVM ditunjukkan pada gambar :

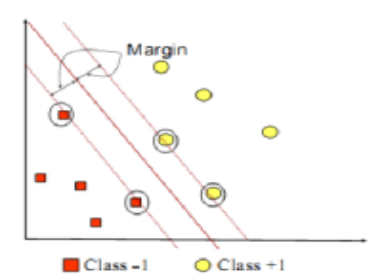

(1)

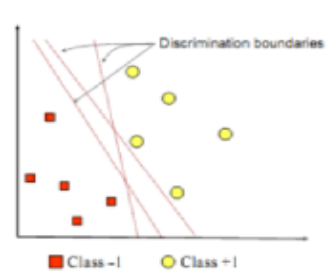

(2)
Hyperplane pemisah terbaik antara kedua class dapat ditemukan dengan mengukur margin hyperplane tersebut. dan mencari titik maksimalnya. Margin adalah jarak antara hyperplane tersebut dengan pattern terdekat dari masing-masing class. Pattern yang paling dekat ini disebut sebagai support vector. Garis solid pada gambar menunjukkan hyperplane yang terbaik, yaitu yang terletak tepat pada tengah-tengah kedua class, sedangkan titik merah dan kuning yang berada dalam lingkaran hitam adalah support vector. Usaha untuk mencari lokasi hyperplane ini merupakan inti dari proses pembelajaran pada SVM [8].

Adapun persamaannya dapat ditunjukkan pada persamaan 1 dan persamaan 2

$x i . w+b \geq+1$ foryi $=+1$

$x i . w+b \leq-1$ foryi $=-1$

Dimana normal bidang ditunjukkan dengan $\mathrm{w}$ dan $\mathrm{b}$ merupakan posisi bidang relatif terhadap pusat koordinat. Adapun nilai margin antar bidang pembatas dapat ditunjukkan pada persamaan

$\frac{1-b-(-1-b)}{w}=\frac{2}{w}$

\section{IMPLEMENTASI}




\section{Deskripsi Umum Sistem}

Dalam penelitian ini, peneliti membuat sebuah sistem yang dapat melakukan klasifikasi tingkat kematangan buah melon.

Gambaran umum sistem yang akan dibuat dalam sistem ini adalah terdapat pada gambar dibawah ini :

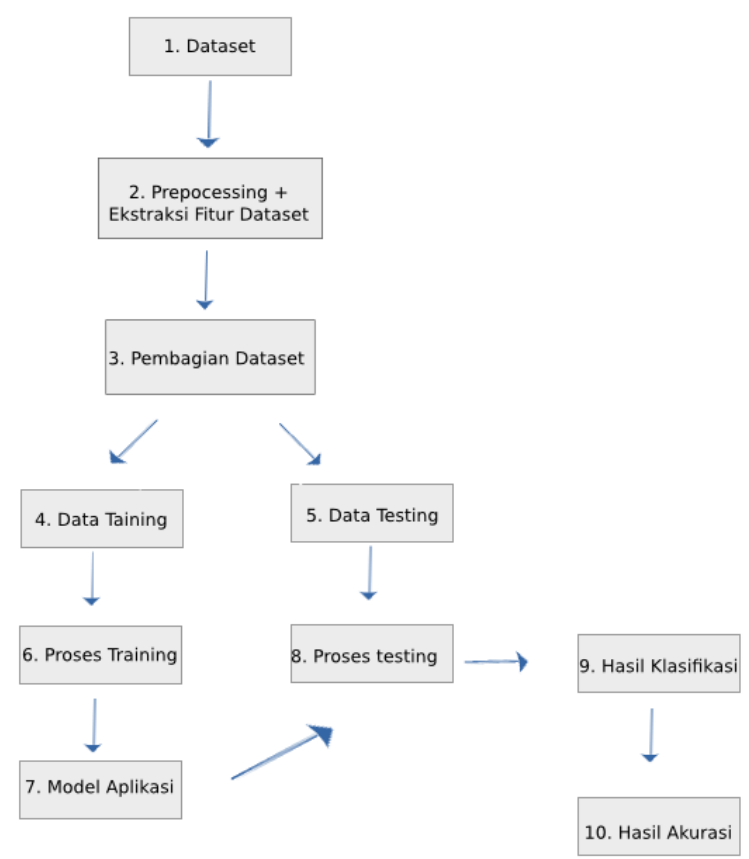

\section{Dataset}

Data yang digunakan pada penelitian ini adalah foto buah melon yang diperoleh secara sampling berdasarkan umur buah melon yaitu melon berumur 45 - 50 hst sebanyak 150 buah (melon tidak matang), melon berumur 51 - 59 hst sebanyak 150 buah (melon setengah matang), dan melon berumur $61-70 \mathrm{hst}$ sebanyak 150 buah (melon matang). Data ini diperoleh dari petani melon yang berada di lokasi Jawa Timur, Siak Pekanbaru, dan Solo.

\section{Prepocessing dan Ekstraksi Ciri Statistik}

\section{A. Prepocessing}

Proses preprocessing bertujuan memperbaiki kualitas dari citra buah melon. Beberapa hal yang dilakukan pada proses ini adalah

\section{Image Kropping}

Image Cropping atau pemotongan citra bertujuan mengambil sebagian informasi berupa citra yang lebih kecil. Area yang diambil merupakan area dari buah melon tersebut sehingga tidak ada areaberupak backgroud dari citra buah melon. Proses kropping pada penelitian kali ini menggunakan tools inkscape.
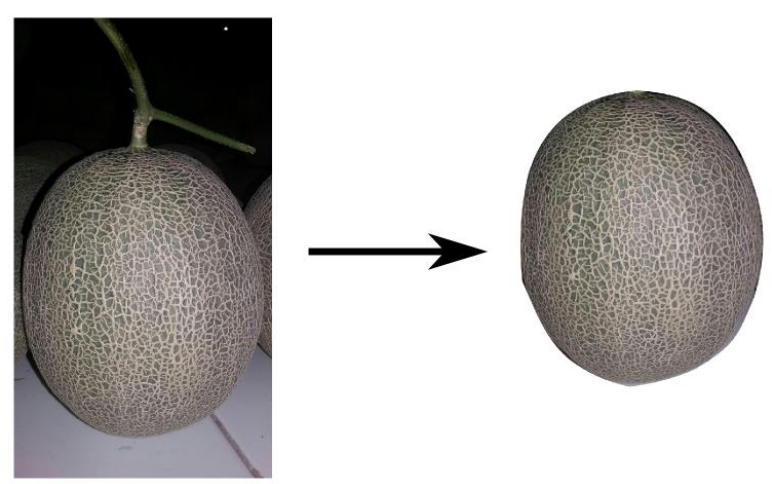

\section{Image Enhancement}

Proses ini merupakan proses untuk memperbaiki kualitas dari citra buah melon, proses pertama yang dilakukan adalah konversi nilai RGB ke bentuk Gray Scale, setelah memperbaiki noise yang terdapat pada buah melon menggunakan median blur, dan terakhir proses yang dijalankan adalah adaptife treshold yaitu proses untuk memperoleh ciri dari citra buah melon.
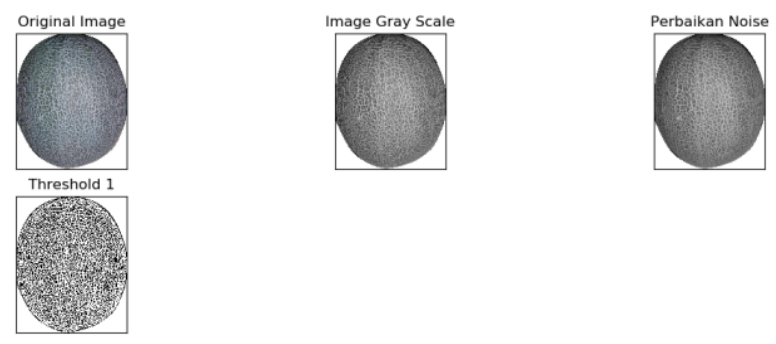

\section{B. Ekstraksi Ciri Statistik}

Ekstraksi ciri merupakan metode pengambilan ciri yang didasarkan pada karakteristik histogram citra. Pada proses ini, citra, citra yang sudah melewati prose adaptive treshold akan dirubah ke bentuk histogram dengan format bentuk array sehingga nilai histogram bisa dilakukan proses training dan testing menggunakan svm.

\section{SVM}

\section{a. Training SVM}

Proses ini merupakan langkah awal klasifikasi menggunakanmetode SVM. Proses training SVM bertujuan untuk mendapatkan informasi hyperplane, 
support vector, dsb yang direpresentasikan ke dalam sebuah struct. Struct didapat dari pelatihan binary class

atau dua kelas yang berbeda. Pada proses ini akan didapkan sebuah model,sehingga model ini dapat digunakan untuk proses testing.

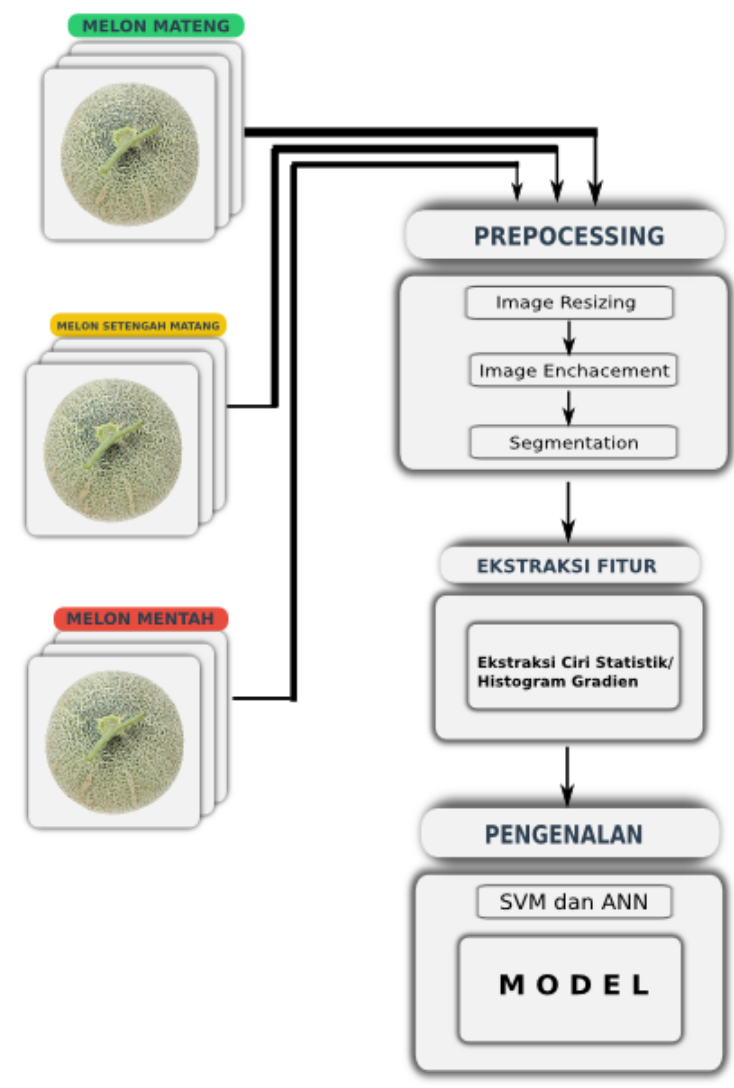

Proses awal yang dilakukan pada tahapan taining ini adalah akuisisi citra menggunakan kamera, kemudian pada citra tersebut dilakuan pengolahan citra. Pada pengolahan citra proses pertama yang dilakukan adalah proses kropping untung mendapatkan citra melon secara utuh tanpa adanya backgroud dari citra melon tersebut, setelah itu dilanjutkan ke proses peningkatan kualitas citra (image enhancement). Pada proses ini dilakukan beberapa operasi citra yang berfungsi untuk meningkatkan kualitas citra seperti medianblur, dan lain sebagainya. Setelah diperoleh data citra dengan ukuran dan kualitas yang baik, maka tahapan berikutnya adalah melakukan pengambilan ciri citra menggunakan metode Ekstraksi Ciri Statistik,Tujuan dari proses ini adalah untuk mendapatkan ciri dari jaring - jaring kulit buah melon. Setelah itu, proses terakhir yang dilakukan adalah pengambilan keputusan menggunakan metode Support Vector Machine (SVM). Melalui proses ini akan diperoleh model algoritma dari buah melon matang, setengah matang, dan mentah.

\section{b. Proses Testing}

Pada tahapan ini dilakukan testing terhadap model algoritma yang telah didapatkan pada saat proses training, sehingga melalui proses testing ini akan diperoleh hasil dari akurasi pengklasifikasian tingkat kematangan buah melon menggunakan metode ekstraksi ciri statistik dan support vector machine.

\section{HASIL}

Dengan menggunakan metode ekstraksi ciri statistik melalui gradien histogram dengan metode support vector machine dapat mengklasifikasikan tingkat kematangan buah melon. Kedua metode tersebut perlu dilengkapi fitur ekstraksi ciri untuk membantu pengenalan ciri dari tekstur kulit buah melon. Untuk tahapan awal dalam proses training dan ekstraksi fitur dilakukan di komputer diman proses pembelajaran dilakukan dengan menggunakan 300 citra buah melon yang terbagi atas 100 citra buah melon matang, 100 citra buah melon setengah matang dan 100 citra buah melon belum matang yang diekstraksi fiturnya dengan menggunakan metode ekstraksi ciri statistik. Proses ekstraksi fitur akan dirubah ke bentuk histogram dimana selanjutnya data akan dirubah kedalam format array untuk selanjutnya dilakukan proses testing menggunakan metode SVM. Dalam penelitian ini, data testing yang digunakan sebanyak 150 citra buah melon yang terdiri dari 50 citra buah melon matang, 50 citra buah melon setengah matang dan 50 citra buah melon belum matang. Sehingga dalam proses klasifikasi ini menghasilkan akurasi sebesar $76.00 \%$.

Berikut kami lampirkan beberapa hasil klasifikasi tingkat kematangan buah melon dengan menggunakan metode ekstraksi ciri statistik dan SVM

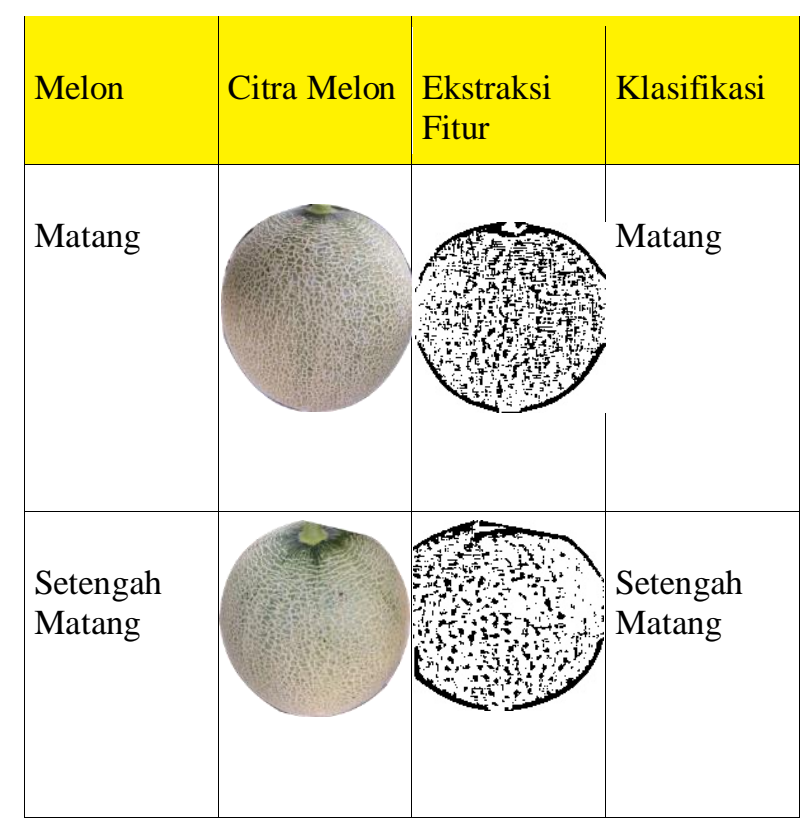




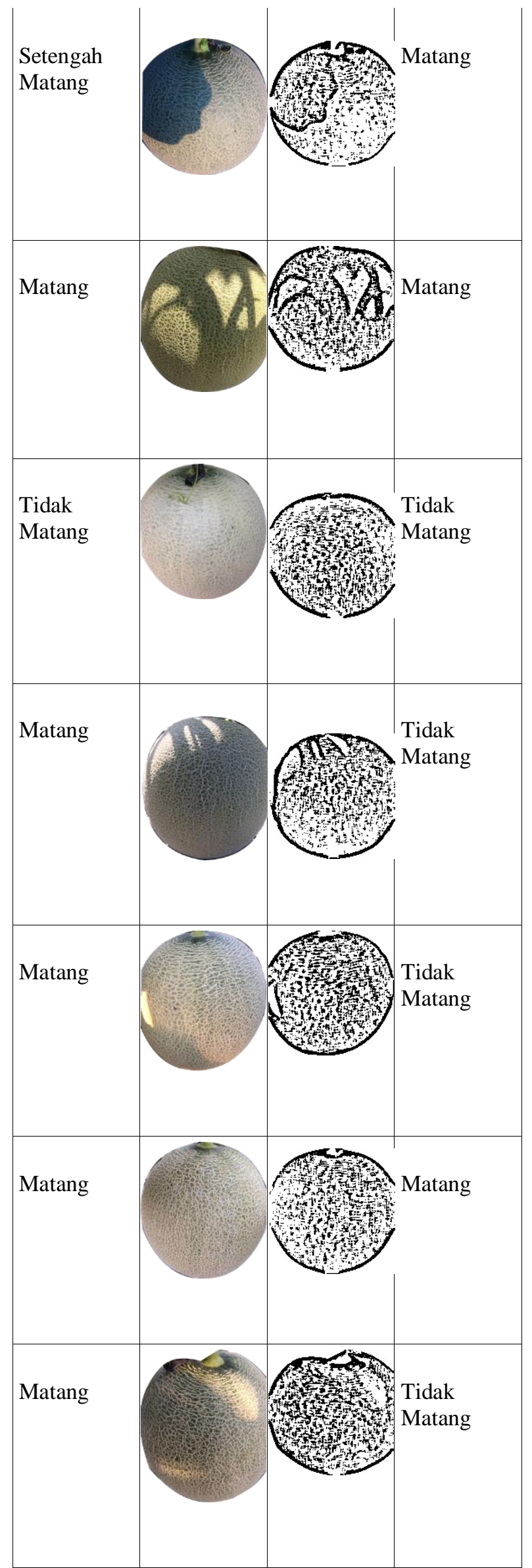

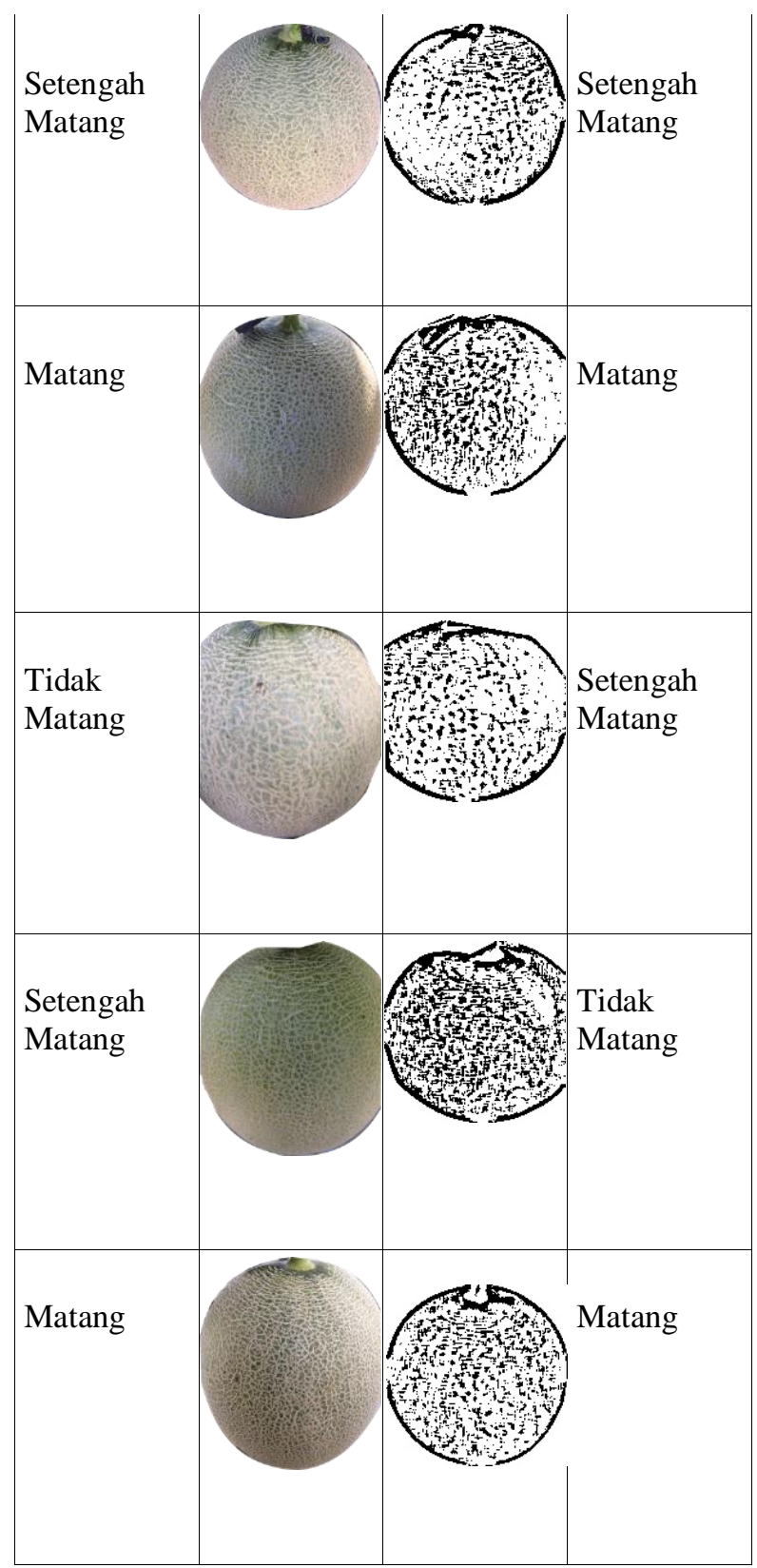

\section{KESIMPULAN}

Berdasarkan penelitian ini, dapat diperoleh kesimpulan bahwa :

1. Mendeteksi tingkat kematangan buah melon berdasarkan tekstur kulit buah dapat distandardisasikan.

2. Metode Ekstraksi Ciri Statistik dan Support Vector Machine dapat mendeteksi tingkat kematangan buah melon berdasarkan tekstur kulit buah.

3. Akurasi metode Ekstraksi Ciri Statistik dan Support Vector Machine dalam mendeteksi tingkat kematangan buah melon berdasarkan tekstur kulit buah adalah $76.00 \%$. 


\section{Harapan dan Saran}

Dengan adanya penelitian ini, diharapakan dapat dijadikan pembelajaran bagi masyarakat dalam mendeteksi kematangan buah melon, dan diharapkan sistem ini dapat dikembangkan dengan melakukan metode-metode lainnya untuk mendeteksi tingkat kematangan buah melon sehingga didapatkan akurasi yang lebih baik daripada metode ini.

\section{DAFTAR PUSTAKA}

[1] Kusumaliski, Nariratri. 2015. Pengembangan Metode Deteksi Kematangan Melon (Cucumis melo L.) Dengan Respon Impuls Akustik. Skripsi. Tidak di terbitkan. Departemen Teknik Mesin Dan Biosistem Fakultas Teknologi Pertanian Institut Pertanian Bogor: Bogor

[2] Sobir dan Firmansyah D. Siregar. 2010. Budi Daya Melon Unggul. Jakarta: Penebar Swadaya

[3] Samadi, B. 2007. Melon, Usaha Tani dan Penanganan Pascapanen. Kanisius. Yogyakarta
[4] Kementrian Pertanian Direktorat Jendral Holtikultura. 2005. Statistik Produksi Holtikultura Tahun 2014. Direktur Jenderal

Holtikultural,Kementrian Pertanian

[5] Munir, Rinaldi. 2004. Pengolahan Citra Digital dengan pendekatan Algoritmik. Bandung : Informatika.

[6] Munir, R., 2004, Pengolahan Citra Digital dengan Pendekatan Algoritmik, Informatika, Bandung.

[7] Arief, Siska Riantini. 2011. Analisis Tekstur dan Ekstraksi Ciri, Program Studi Teknik Informatika, Institut Teknologi Telkom Bandung.avalaible at: http://www.ittelkom.ac.id/.

[8] James Sanger Ronen Feldman, The Text Mining Handbook. New York: Cambridge University Press, 2007.

[9] Prasetyo, Eko. 2012. "Data Mining - Konsep dan Aplikasi Menggunakan Matlab”. Andi Offset: Yogyakarta. 